\title{
The Role of Opioid Receptor Subtypes in the Development of Behavioral Sensitization to Ethanol
}

\author{
Raúl Pastor' and Carlos MG Aragon*,' \\ 'Area de Psicobiología, Universitat Jaume I, Castelló, Spain
}

\begin{abstract}
Nonspecific blockade of opioid receptors has been found to prevent development of behavioral sensitization to ethanol. Whether this effect is achieved through a specific opioid receptor subtype, however, is not clear. The present study investigated, for the first time, the role of specific opioid receptor subtypes in the development of ethanol- $(2.5 \mathrm{~g} / \mathrm{kg} / \mathrm{day}$; six sessions) induced locomotor sensitization in mice. We confirmed previous results showing that the nonspecific antagonism of opioid receptors (naltrexone; $0-2 \mathrm{mg} / \mathrm{kg}$ ) prevented the development of behavioral sensitization to ethanol, an effect attained at doses presumed to occupy only mu opioid receptors. This was confirmed by using the selective mu opioid receptor antagonist CTOP (0-1.5 mg/kg), which also blocked sensitization to ethanol. The selective delta receptor antagonist, naltrindole $(0-10 \mathrm{mg} / \mathrm{kg})$, however, did not alter sensitization. We further assessed the role of mu opioid receptors in sensitization to ethanol by exploring the involvement of $\mathrm{mu}_{1}, \mathrm{mu}_{1}+2$, and $\mathrm{mu}_{3}$ opioid receptor subtypes. Results of these experiments revealed that the blockade of $\mathrm{mu}_{1}$ (naloxonazine; 0-30 mg/kg) or mu $\mathrm{m}_{3}$ opioid receptors (3-methoxynaltrexone; 0$6 \mathrm{mg} / \mathrm{kg}$ ) did not prevent locomotor sensitization to ethanol. Using naloxonazine under treatment conditions that block mu $1+2$ opioid receptor subtypes we observed a retarded sensitization. The present data suggest that the concurrent inactivation of all mu opioid receptor subtypes may be required to prevent the neural adaptations underlying the development of behavioral sensitization to ethanol. In addition, these results support previous data suggesting a putative role for the mu opioid receptor endogenous ligand, $\beta$-endorphin, and the hypothalamic arcuate nucleus in ethanol sensitization.

Neuropsychopharmacology (2006) 3 I, | 489- |499. doi: | 0.1038/sj.npp. I 300928; published online 12 October 2005
\end{abstract}

Keywords: ethanol; behavioral sensitization; mu opioid receptor; $\beta$-endorphin

\section{INTRODUCTION}

When repeatedly administered, drugs of abuse produce persistent increases in both their psychomotor stimulating effects (Badiani et al, 2000; Kalivas et al, 1992; Phillips et al, 1994) and their incentive motivational properties (Lett, 1989; Piazza et al, 1989; Robinson and Berridge, 1993), a phenomenon known as behavioral sensitization. The neural changes that underlie behavioral sensitization to drugs of abuse are thought to contribute to the transfer from moderate consumption to the compulsive patterns of drugseeking and drug-craving that characterizes addictive behavior (Robinson and Berridge, 1993; Stewart and Badiani, 1993). Elucidating the neurochemistry of drug sensitization, therefore, can provide helpful insights into the understanding of the development of addiction.

In search of a common neurochemical substrate underlying the sensitization process to drugs of abuse, the glutamatergic and the dopaminergic systems have been

\footnotetext{
*Correspondence: Dr CMG Aragon, Area de Psicobiología, Universtitat Jaume I, Campus de Riu Sec, Avda. Sos Baynat s/n, 1207| Castelló, Spain, Tel: + 34964 729835, Fax: + 34964729267 ,

E-mail: aragon@psb.uji.es

Received 27 May 2005; revised 29 July 2005; accepted 30 August 2005 Online publication: 2 September 2005 at http://www.acnp.org/ citations/Npp090205050354/default.pdf
}

repeatedly implicated (Robinson and Berridge, 1993; Vanderschuren and Kalivas, 2000; Vezina and Kim, 1999). With respect to ethanol, however, data reveal a controversial role of those systems in explaining the development of behavioral sensitization. It has been proposed that the activation of the $N$-methyl-D-aspartate (NMDA) subclass of glutamate receptors is necessary for the development of ethanol sensitization in mice (Broadbent et al, 2003; Camarini et al, 2000a). However, when further investigated, it has been reported that this effect is related to the action of NMDA antagonists on acute ethanol-induced locomotor activity (Meyer and Phillips, 2003). In fact, an enhanced, rather than attenuated sensitized response to ethanol has been found using low doses of the NMDA antagonist MK801, which increased the stimulatory acute effects of ethanol (Meyer and Phillips, 2003). Sensitization to ethanol has also been associated with increases in dopamine (DA) $D_{2}$ receptor binding (Souza-Formigoni et al, 1999). Deletion of the DA $\mathrm{D}_{2}$ receptor gene in mice, however, did not alter ethanol-induced sensitization (Palmer et al, 2003); additionally, the nonspecific DA receptor antagonist, haloperidol, has been shown to not block this effect of ethanol (Broadbent et al, 1995). The involvement of other systems in ethanol sensitization, such as $\gamma$-aminobutyric acid (GABA) neurotransmission, has been additionally proposed. However, data indicate that ethanol sensitization 
may not be associated with changes in $\mathrm{GABA}_{\mathrm{A}}$ receptor function (Meyer et al, 2005).

A critical role of the opioid system in the sensitizing effects of ethanol in mice has recently been proposed (Camarini et al, 2000b; Miquel et al, 2003). Nonselective antagonism of opioid receptors with naloxone has been shown to block the development of ethanol sensitization (Camarini et al, 2000b). While both naloxone and naltrexone are characterized as nonspecific opioid receptor antagonists, they have been found to have a higher affinity for $\mathrm{mu}$ than for delta opioid receptors (Takemori and Portoghese, 1984; Williams et al, 2001). Low doses of naloxone and naltrexone (eg $1 \mathrm{mg} / \mathrm{kg}$ and less) are suggested to be specific for the mu opioid receptor, whereas higher doses may additionally recruit delta opioid receptors (Mhatre and Holloway, 2003; Takemori and Portoghese, 1984). According to this, data from experiments showing a blockade of ethanol sensitization with opioid antagonists suggest that mu opioid receptors may be particularly involved in ethanol sensitization (Camarini et al, 2000b). However, the hypothesis that behavioral sensitization to ethanol is specifically achieved through mu opioid receptors needs to be assessed.

Recent data suggest that the acute locomotor stimulating effects of ethanol are mediated by mu, but not delta opioid receptors (Hall et al, 2001; Pastor et al, 2005; Sanchis-Segura et al, 2004). In addition, it has been proposed that acute ethanol stimulation may be selectively mediated by some of the subtypes of the mu opioid receptor. Specifically, the antagonism of $\mathrm{mu}_{1+2}$ or $\mathrm{mu}_{3}$, but not $\mathrm{mu}_{1}$ receptors, have been found to attenuate behavioral stimulation induced by acute ethanol administration (Pastor et al, 2005). Whether the functional relevance of these mu receptor subtypes could be extended to the chronic effects of ethanol on locomotor activity, however, is not known.

One goal of the present study was to test the hypothesis that the development of sensitization to the locomotor stimulatory effects of ethanol is specifically mediated by $\mathrm{mu}$ opioid receptors. This was accomplished by comparing the effects of naltrexone on ethanol sensitization to those obtained with D-Pen-Cys-Tyr-D-Trp-Orn-Thr-Pen-Thr- $\mathrm{NH}_{2}$ (CTOP) and naltrindole, selective mu and delta opioid receptor antagonists, respectively. A second goal of the current study was to explore a putative involvement of $\mathrm{mu}$ opioid receptor subtypes $\left(\mathrm{mu}_{1}, \mathrm{mu}_{1+2}\right.$, or $\left.\mathrm{mu}_{3}\right)$ in the sensitizing effects of ethanol. This objective was addressed by using naloxonazine (which can be used as $\mathrm{mu}_{1}$ or a $\mathrm{mu}_{1+2}$ antagonist) and 3-methoxynaltrexone $\left(\mathrm{mu}_{3}\right.$ antagonist). Although there are many types of behavioral sensitization (ie sensitization to stereotypic behavior), the present article only involves studies of locomotor sensitization, and therefore the term sensitization will hereafter be used to refer specifically to locomotor sensitization.

\section{MATERIALS AND METHODS}

\section{Subjects and Housing}

Male Swiss (IOPS Orl) albino mice, a strain chosen for its sensitivity to the stimulatory and sensitizing effects of ethanol (Camarini et al, 2000b; Miquel et al, 2003), were purchased from Janvier Spain, SA (Barcelona, Spain), housed (three per cage) and acclimated to the colony room for at least 2 weeks prior to study initiation. At the time of testing, mice were 6 weeks old. The colony was maintained in a humidity- (50\%) and temperature-controlled $\left(22 \pm 1^{\circ} \mathrm{C}\right)$ environment under a 12-h light/dark cycle (lights on at 0800) with standard laboratory rodent chow (Panlab SL, Spain) and tap water available ad libitum. Behavioral testing occurred between 1000 and 1400. All experimental procedures complied with the European Community Council Directive (86/609/ECC) for the use of laboratory animal subjects.

\section{Drug Sources and Preparation}

Ethanol (Panreac SA, Spain) was diluted to $20 \%(\mathrm{v} / \mathrm{v})$ in $0.9 \%$ physiological saline from $96 \%$ solutions. This concentration of ethanol was selected based on previous studies (Pastor et al, 2002; Sanchis-Segura et al, 2004) showing no signs of toxicity after intraperitoneal (i.p.) injections. Naltrexone, CTOP, naltrindole, naloxonazine, and 3-methoxynaltrexone were obtained from Sigma-Aldrich Química (Spain) and were administered (i.p.) in an injection volume of $10 \mathrm{ml} / \mathrm{kg}$. All solutions were prepared fresh daily in saline except naloxonazine, which was dissolved in a tartaric acid solution (TA; $0.2 \% \mathrm{w} / \mathrm{v})$ in saline. This concentration of TA was chosen because it did not affect spontaneous locomotor activity (Pastor et al, 2005). Saline solution was administered to control groups. However, in experiments involving naloxonazine, control groups were injected with vehicle $(0.2$ $\% \mathrm{w} / \mathrm{v} \mathrm{TA}$, in saline).

\section{Locomotor Activity Test}

All subjects were tested in open-field chambers consisting of cylinders $25 \mathrm{~cm}$ in diameter and $30 \mathrm{~cm}$ high. Locomotor activity was registered by a computerized video-tracking system (Ethovision 2.0., Noldus, The Netherlands). Movement of the animal within the open-field was automatically recorded and later translated by Ethovision software to horizontal distance traveled (in $\mathrm{cm}$ ), which served as the dependent variable for the present behavioral studies. The duration of the test was $20 \mathrm{~min}$, however, as previously described (Pastor et al, 2002), only the last $15 \mathrm{~min}$ were considered for statistical analyses. This interval of time was chosen in order to ensure the absorption and distribution of ethanol within the CNS after its i.p. injection (Quertemont et al, 2003) and to minimize a possible masking effect of nonspecific locomotor activation derived from handling, injections, and experimental novelty, which is particularly present in the first minutes of the test (Dudek and Tritto, 1994; Kelley, 1993). We confirmed, moreover, that all main effects found in the present study were also present when the total $20 \mathrm{~min}$ test was analyzed. Behavioral testing was conducted in sound-attenuated rooms $\left(8 \mathrm{~m}^{2}\right)$ with dim illumination $(20 \mathrm{~W}$; regular white light) to minimize stress induced by highly illuminated environments.

\section{Behavioral Procedures}

Six separate experiments were conducted using a common experimental design (presented in Table 1). Based on previous literature (Meyer and Phillips, 2003; Miquel et al, 
2003), the sensitization protocol was divided into two phases: treatment and challenge. The treatment phase (days 1-11) involved six trials on alternate days, one trial per day. On each behavioral test day of this phase (days $1,3,5,7,9$, and 11), mice received saline, naltrexone, CTOP, naltrindole, naloxonazine, or 3-methoxynaltrexone prior to a saline or ethanol injection and were individually placed in the open-field chamber immediately after the second injection. On days $2,4,6,8$, and 10 mice were left undisturbed in the colony room. The treatment phase allowed us to study the effect of opioid antagonists on the development of sensitization to the locomotor stimulating actions of ethanol. A period of 7 days without any experimentation separated the treatment and the challenge phase. The challenge phase involved two trials: the ethanol challenge (day 18), in which all mice received an injection of ethanol immediately before locomotor activity testing, and the saline challenge (day 19), which paralleled the ethanol challenge except that all mice received an injection of saline instead of ethanol. The aim of the challenge phase was twofold. First, to assess whether sensitization was impeded by the presence of opioid antagonists and to study whether opioid antagonists altered the duration of sensitization. Second, the saline challenge was conducted to study possible conditioned locomotor effects induced by the testing environment where ethanol-stimulated behavior occurred. Dosage and timing between pretreatment and treatment injections (detailed in Table 1) were undertaken as follows: Naltrexone $(0,1$, or $2 \mathrm{mg} / \mathrm{kg})$ was given $30 \mathrm{~min}$ before saline or ethanol, naltrindole $(0,5$, or $10 \mathrm{mg} / \mathrm{kg})$ was

Table I Schedule of Injections for Experimental Groups

Treatment phase

Days I, 3, 5, 7, 9, and II

\section{Group}

Exp. 1

S-S

S-E

$N X-S$

$N X-E$

Exp. $2 b$

S-S

S-E

CTOP-S

CTOP-E

Exp. 3

\section{S-S}

S-E

ND-S

ND-E
Saline

Saline

CTOP

CTOP
Time between injections
Treatment

$30 \mathrm{~min}$

$30 \mathrm{~min}$

$30 \mathrm{~min}$

$30 \mathrm{~min}$

Saline
Ethanol
Saline
Ethanol

Saline

Ethanol

Saline

Ethanol
Challenge phase

Day 18 Day 19

Treatment

Treatment

\section{Saline \\ Saline \\ Saline \\ Saline}

\section{Exp. 4 and 5}

$\begin{array}{ll}V-S & \text { Vehicle } \\ V-E & \text { Vehicle } \\ \text { NZ-S } & \text { Naloxonazine } \\ \text { NZ-E } & \text { Naloxonazine }\end{array}$

$\begin{array}{ll}20 \mathrm{~h} / 15 \mathrm{~min} & \text { Saline } \\ 20 \mathrm{~h} / 15 \mathrm{~mm} & \text { Ethanol } \\ 20 \mathrm{~h} / 15 \mathrm{~min} & \text { Saline } \\ 20 \mathrm{~h} / 15 \mathrm{~min} & \text { Ethanol }\end{array}$

Saline
Ethanol
Saline
Ethanol

$15 \mathrm{~min}$

$15 \mathrm{~min}$

$15 \mathrm{~min}$

15 min

Naltrindole

Naloxonazine
Saline

Saline

3-Methoxynaltrexone

3-Methoxynaltrexone

\begin{tabular}{lllll} 
S-S & Saline & $0 \mathrm{~min}$ & Saline & Ethanol Saline \\
S-E & Saline & $0 \mathrm{~min}$ & Ethanol & Ethanol Saline \\
MTX-S & 3-Methoxynaltrexone & $0 \mathrm{~min}$ & Saline & Ethanol \\
MTX-E & 3-Methoxynaltrexone & $0 \mathrm{~min}$ & Ethanol & Ethanol \\
\hline
\end{tabular}

Ethanol

Saline

Ethanol

Saline

Ethanol

Ethanol

Ethanol

Ethanol

Ethanol

Saline

Saline

Ethanol

Exp. 6

Ethanol was injected at the dose of $2.5 \mathrm{~g} / \mathrm{kg}$. Naltrexone doses: I or $2 \mathrm{mg} / \mathrm{kg}$; CTOP doses: I or $1.5 \mathrm{mg} / \mathrm{kg}$; Naltrindole: 5 and $10 \mathrm{mg} / \mathrm{kg}$. Naloxonazine doses were I5 or $30 \mathrm{mg} / \mathrm{kg}$ when given $20 \mathrm{~h}$ before saline or ethanol and 10 or $15 \mathrm{mg} / \mathrm{kg}$ when given $15 \mathrm{~min}$ before. 3-Methoxynaltrexone doses: 3 or $6 \mathrm{mg} / \mathrm{kg}$. During the treatment phase, mice were left undisturbed on days 2, 4, 6, 8, and I0. No experiments were conducted during the 7-day period between the treatment and the challenge phase. Locomotor activity was measured immediately following the treatment injection. 
injected $15 \mathrm{~min}$ prior to saline or ethanol, while naloxonazine was given under two different treatment conditions: $15 \mathrm{~min}$ or $20 \mathrm{~h}$ before saline or ethanol. In this respect, radioligand binding studies have demonstrated that naloxonazine has a long-lasting (20 h after its administration) action as a specific $\mathrm{mu}_{1}$ opioid receptor antagonist after an immediate transitory blockade of $\mathrm{mu}_{1+2}$ receptors (Ling et al, 1986). In the present study we compared the effects of naloxonazine on ethanol sensitization when blocking $\mathrm{mu}_{1}$ to those obtained when antagonizing $\mathrm{mu}_{1+2}$ opioid receptors. When naloxonazine was given $20 \mathrm{~h}$ before ethanol, doses of naloxonazine were 0,15 , or $30 \mathrm{mg} / \mathrm{kg}$. When given $15 \mathrm{~min}$ before ethanol, doses were 0,10 , or $15 \mathrm{mg} / \mathrm{kg}$. 3-Methoxynaltrexone $(0,3$, or $6 \mathrm{mg} / \mathrm{kg})$ was administered immediately before saline or ethanol. Doses of naltrexone, naltrindole, naloxonazine, and 3-methoxynatrexone were selected based on studies involving ethanolinduced behaviors in rodents, including acute ethanol stimulation (Ciccocioppo et al, 2002; Honkanen et al, 1996; Mhatre and Holloway, 2003; Pastor et al, 2005; Sanchis-Segura et al, 2004). As there were no previous data showing CTOP effects on ethanol-induced locomotor behaviors, we examined the effect of this compound on acute ethanol stimulation (experiment $2 \mathrm{a}$ ). Taken from this experiment, doses of CTOP tested for sensitization were 1 and $1.5 \mathrm{mg} / \mathrm{kg}$. The same dose of ethanol $(2.5 \mathrm{~g} / \mathrm{kg})$ was used for the treatment and the challenge phase; this dose was selected based on previous studies showing that it significantly increases horizontal locomotion in mice (Pastor et al, 2002; Sanchis-Segura et al, 2004). For all experiments, mice were moved from the colony room to the testing room and left undisturbed at least 30-45 min prior to experimentation to permit acclimation to the testing environment. Group size was 9-12 mice in all experiments: a total of 54-60 animals per experiment were used.

\section{Determination of Blood Ethanol Levels}

To study whether naltrexone and CTOP (the two compounds that prevented the development of ethanol sensitization) altered blood ethanol levels (BEL), a separate experiment was conducted ( $n=6$ per group). This experiment paralleled the injection and timing schedule followed for the behavioral study during the treatment phase; however, no locomotor activity testing was undertaken. Doses of naltrexone and CTOP used in this experiment were 2 and $1.5 \mathrm{mg} / \mathrm{kg}$, respectively. On days 1 and 11 , tail vein blood samples $(20 \mu \mathrm{l})$ were collected $20 \mathrm{~min}$ after ethanol $(2.5 \mathrm{~g} / \mathrm{kg})$ administration. Following Boehm et al (2000), each blood sample was immediately placed in a microcentrifuge tube containing $50 \mu \mathrm{l}$ of ice-cold $5 \% \mathrm{ZnSO}_{4}$ solution. A $50 \mu \mathrm{l}$ aliquot of $0.3 \mathrm{~N} \mathrm{Ba}(\mathrm{OH})_{2}$ and $300 \mu \mathrm{l}$ of deionized water were added. After centrifugation at $4{ }^{\circ} \mathrm{C}$ ( $5 \mathrm{~min}, 12000 \mathrm{rpm}$ ), the supernatant was removed and BELs were determined using head space gas chromatography (CE Instruments GC 8000, HS 850).

\section{Data Analysis}

The dependent variable for all behavioral experiments was distance traveled (in $\mathrm{cm}$ ) during $15 \mathrm{~min}$. For the treatment phase of the experiments, data were analyzed with repeated measures analysis of variance (ANOVA), with the pretreatment, antagonist dose (saline, naltrexone, CTOP, naltrindole, naloxonazine, or 3-methoxynaltrexone) and the treatment, ethanol dose ( 0 or $2.5 \mathrm{~g} / \mathrm{kg}$ ) as the betweengroups variables and test sessions (days 1-11) as the repeated measure. Data from each challenge day (day 18, ethanol; day 19, saline) were analyzed separately, with only pretreatment and treatment as between-groups variables (two-way ANOVA). When significant interactions were obtained, Tukey's honestly significant difference (HSD) tests were used to determine specific differences between groups. Significance levels were set at $\alpha=0.05$. BELs were analyzed using two-way ANOVAs with repeated measures (pretreatment $\times$ trial). All statistical analyses were conduced with the Statistica 6.1 software package (StatSoft, Inc., Tulsa, OK, USA).

\section{RESULTS}

\section{Experiment 1}

Figure 1 shows the effect of repeated ethanol exposure on locomotor activity in mice pretreated with naltrexone. Analysis of the treatment phase supported that our protocol was suitable to induce behavioral sensitization to ethanol, as ANOVA revealed a main effect of ethanol dose $\left(\mathrm{F}_{1,46}=76.16 ; p<0.01\right)$ and a significant ethanol dose $\times$ trial interaction was found to be significant $\left(\mathrm{F}_{5,230}=7.12\right.$; $p<0.01)$. Naltrexone pretreatment prevented the development of ethanol sensitization but it did not affect activity in saline-treated mice; a significant effect of the naltrexone dose $\left(\mathrm{F}_{2,46}=37.15 ; p<0.01\right)$ and an interaction between

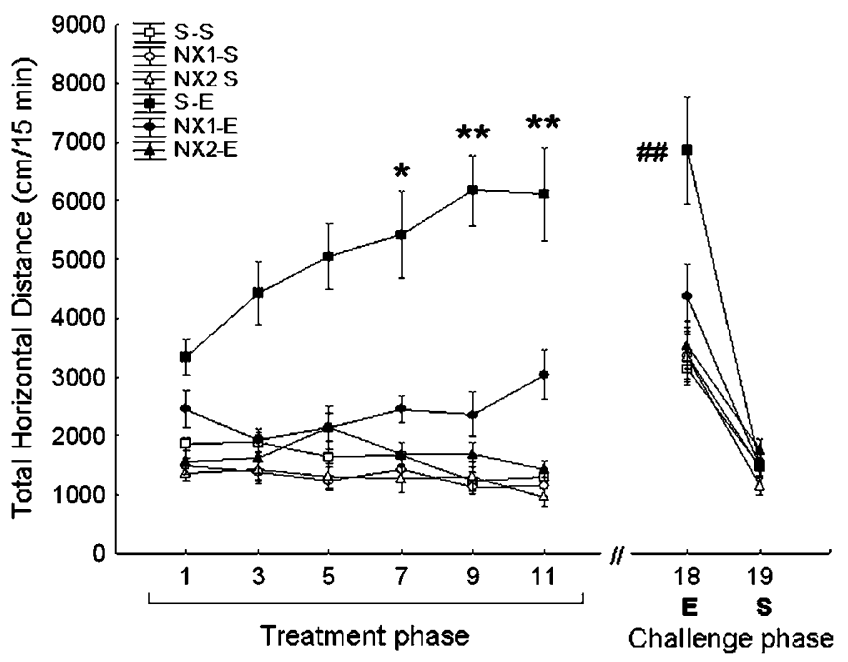

Figure I Effects of naltrexone on ethanol sensitization. Group means $( \pm$ SEM) for the last 15 min of a 20-min test are presented. Numbers in the abscise axis refer to the day of the experiment. On days I-II mice received, every other day, the treatments indicated in the legend ( $S$, saline; $\mathrm{E}$, ethanol; NXI, naltrexone $1 \mathrm{mg} / \mathrm{kg} ; \mathrm{NX} 2$, naltrexone $2 \mathrm{mg} / \mathrm{kg}$ ). On days 18 and 19 all mice received ethanol and saline, respectively. Through all the experiment the ethanol dose was $2.5 \mathrm{~g} / \mathrm{kg}$. Asterisks indicate significant increases in locomotor activity compared with day I of the same group $(* p<0.05, * * p<0.01)$. Number signs indicate significant differences to the rest of the groups tested on day $18\left({ }^{\# \#} p<0.01\right)$. 
naltrexone dose and ethanol dose $\left(\mathrm{F}_{2,46}=25.29 ; p<0.01\right)$ were obtained. The triple interaction (naltrexone dose $\times$ ethanol dose $\times$ trials $)$ was found significative $\left(F_{10,230}=3.98\right.$; $p<0.01)$. Tukey's post hoc comparisons showed that ethanol induced a significant increase in locomotor activity on day 1 ; the saline-ethanol group was different from the rest of the groups $(p<0.05)$ except the naltrexone $1 \mathrm{mg} / \mathrm{kg}$-ethanol group. In the saline-ethanol group, it was found an increased response to ethanol on days $7(p<0.05)$, 9, or $11(p<0.01)$ relative to the acute response to ethanol; however, there were not differences between days 7 and 11, suggesting a ceiling effect of ethanol. All groups, except the saline-ethanol group, were found to not increase (or decrease) their locomotor activity scores across the six test sessions conducted during the treatment phase. With respect to the ethanol challenge, only the saline-ethanol group showed a sensitized response to ethanol. A two-way ANOVA revealed a significant effect of the naltrexone dose $\left(\mathrm{F}_{2,46}=4.7 ; p<0.05\right)$, ethanol dose $\left(\mathrm{F}_{1,46}=14.22 ; p<0.01\right)$ and a significant interaction $\left(\mathrm{F}_{2,46}=7.13 ; p<0.01\right)$, confirming the differences among groups observed during the treatment phase. The saline challenge showed that the treatments applied before this challenge did not affect the locomotor response to a saline injection. With respect to BELs, we tested the effects of $2 \mathrm{mg} / \mathrm{kg}$ of naltrexone on BELs on days 1 and 11, and no effects of this pretreatment were found (day 1, $60 \pm 3.6 \mathrm{mM}$ for the saline-ethanol group, and $63 \pm 4.5 \mathrm{mM}$ for the naltrexone-ethanol group; day 11 , $69 \pm 4.9 \mathrm{mM}$ for the saline-ethanol group, and $72 \pm 3.9 \mathrm{mM}$ for the naltrexone-ethanol group).

\section{Experiment $2 \mathrm{a}$ and $2 \mathrm{~b}$}

Acute ethanol stimulation was tested in animals pretreated with several doses of CTOP (Figure 2a). The stimulant response to ethanol was dose-dependently attenuated by CTOP, an observation supported by the results of a two-way ANOVA that revealed a significant effect of the ethanol treatment $\left(\mathrm{F}_{1,80}=16.34 ; p<0.01\right)$, the pretreatment with CTOP $\left(\mathrm{F}_{4,80}=14.05 ; p<0.01\right)$ and the interaction between the two factors $\left(\mathrm{F}_{4,80}=4.08 ; p<0.01\right)$. Tukey's post hoc tests indicated that mice treated with 1 or 1.5 (but not 0.1 or 0.5 ) $\mathrm{mg} / \mathrm{kg}$ of CTOP in combination with ethanol exhibit no stimulation of locomotor behavior $(p<0.05)$. These doses of CTOP (1 and $1.5 \mathrm{mg} / \mathrm{kg}$ ), which were found to not affect spontaneous locomotor activity, were used to assess the effect of mu opioid receptor blockade on ethanol sensitization (Figure 2b). For the sensitization experiment, ANOVA analyses of the treatment phase revealed a significant main effect of CTOP dose $\left(\mathrm{F}_{2,52}=91.72 ; p<0.01\right)$, ethanol dose $\left(\mathrm{F}_{1,52}=150.58 ; p<0.01\right)$ and their interaction $\left(\mathrm{F}_{2,52}=63.30\right.$; $p<0.01$ ). The repeated tests (trial factor) were found to interact with ethanol $\left(\mathrm{F}_{5,260}=3.48 ; p<0.05\right)$ and CTOP dose $\left(\mathrm{F}_{10,260}=3.72 ; p<0.05\right)$. The triple interaction was also found statistically significant $\left(\mathrm{F}_{10,260}=3.28 ; p<0.05\right)$. Tukey's tests confirmed that both CTOP doses attenuated acute ethanol stimulation $(p<0.05)$. Post hoc tests comparing within-group values showed that, across the six trials of the treatment phase, no differences in locomotor activity (increases or decreases) were found except for the salineethanol group, which displayed an increased response to ethanol on days 7, $9(p<0.05)$, and $11(p<0.01)$ as
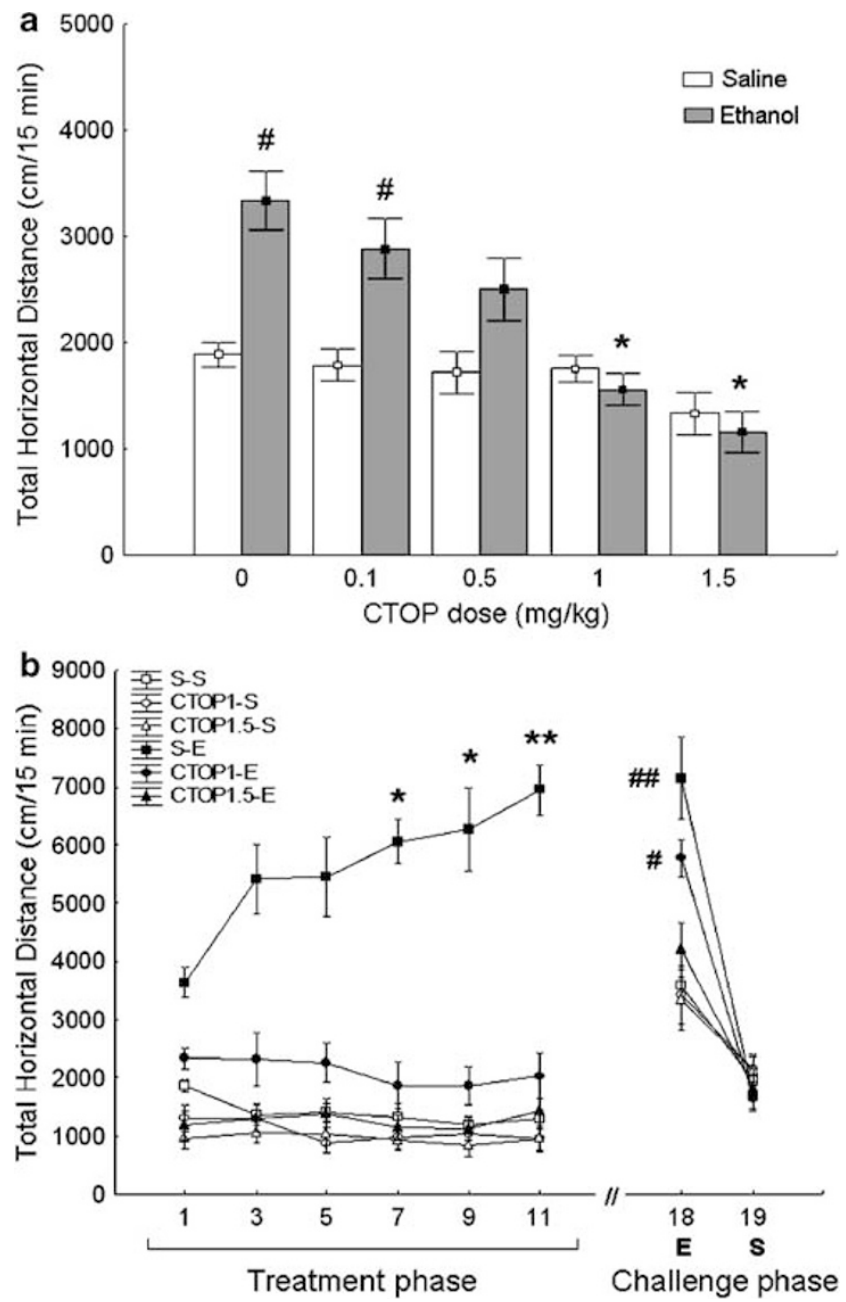

Figure 2 (a) Effects of CTOP on acute ethanol stimulation. Group means $( \pm$ SEM $)$ for the last 15 min of a 20 -min test are presented. Animals were pretreated with CTOP $(0,0.1,0.5$, I or $1.5 \mathrm{mg} / \mathrm{kg})$ and challenged with ethanol (0 or $2.5 \mathrm{~g} / \mathrm{kg}$ ) 15 min after CTOP administration (* $p<0.05$ significantly different from the saline-ethanol group; ${ }^{*} p<0.05$ significantly different from the saline-saline group). (b) Effects of CTOP on ethanol sensitization. Group means ( \pm SEM) for the last I 5 min of a 20-min test are presented. Numbers in the abscise axis refer to the day of the experiment. On days $|-1|$ mice received, every other day, the treatments indicated in the legend. (S, saline; E, ethanol; CTOPI, CTOP I mg/kg; CTOPI.5, CTOP $1.5 \mathrm{mg} / \mathrm{kg}$ ). On days 18 and 19 all mice received ethanol and saline, respectively. Ethanol dose was $2.5 \mathrm{~g} / \mathrm{kg}$. Asterisks indicate significant increases in locomotor activity compared with day I of the same group $\left({ }^{*} p<0.05, * * p<0.0 \mathrm{I}\right)$. Number signs indicate significant differences to groups also tested on day 18. ${ }^{\#}$ indicates different from the rest of the groups except $S-E(p<0.05)$. \# indicates different from the rest of the groups except CTOPI-E $(p<0.0 \mathrm{I})$.

compared to day 1 . The prevention of sensitization by CTOP was found only at the dose of $1.5 \mathrm{mg} / \mathrm{kg}(p<0.01$ compared to saline-ethanol), as data from the ethanol challenge displayed a sensitized response to ethanol in the group pretreated with $1 \mathrm{mg} / \mathrm{kg}$ of CTOP and treated with ethanol. Analyses of this challenge revealed a significant main effect of the pretreatment $\left(\mathrm{F}_{2,52}=8.07 ; p<0.01\right)$, treatment $\left(\mathrm{F}_{1,52}=33.51 ; p<0.01\right)$, and a significant interaction $\left(\mathrm{F}_{2,52}=3.34 ; p<0.05\right)$. The locomotor activity measured after a saline injection (day 19) was found not 
different among groups. On days 1 and 11, BELs were determined in animals pretreated with $1.5 \mathrm{mg} / \mathrm{kg}$ of CTOP; no effects of this pretreatment were found. Data were $64 \pm 4.9 \mathrm{mM}$ for the saline-ethanol group and $67 \pm 5.8 \mathrm{mM}$ for the CTOP-ethanol group on day 1 and $73 \pm 4.5 \mathrm{mM}$ for the saline-ethanol group and $71 \pm 4.7 \mathrm{mM}$ for the CTOPethanol group on day 11 .

\section{Experiment 3}

As shown in Figure 3, the selective delta opioid receptor antagonist naltrindole did not affect ethanol sensitization. Ethanol induced a robust acute locomotor stimulant effect that significantly increased across test sessions, indicating behavioral sensitization; this effect was obtained regardless of the naltrindole dose. These conclusions were supported by the results of the ANOVA, which showed a significant effect of ethanol $\left(\mathrm{F}_{1,48}=420.74 ; p<0.01\right)$ and an ethanol $\times$ trial interaction $\left(\mathrm{F}_{5,240}=18.95 ; p<0.01\right)$. The trial factor was also found statistically significant $\left(\mathrm{F}_{5,240}=12.82 ; p<0.01\right)$. The lack of an effect of naltrindole pretreatment was also present when tested a week after the treatment phase. A two-way ANOVA for the ethanol challenge revealed that all groups repeatedly treated with ethanol during the treatment phase, regardless of naltrindole dose, displayed a sensitized response to ethanol, which was manifested as a main effect of ethanol dose $\left(\mathrm{F}_{1,48}=46.89 ; p<0.01\right)$, but not naltrindole dose was found. In addition, no interaction between the two factors was found. With respect to the saline challenge, as occurred in experiments 1 and $2 \mathrm{~b}$, experimental groups did not differ in the locomotor response to saline.

\section{Experiments 4 and 5}

The effects of naloxonazine on ethanol sensitization are presented in Figures 4 and 5, as this opioid antagonist was

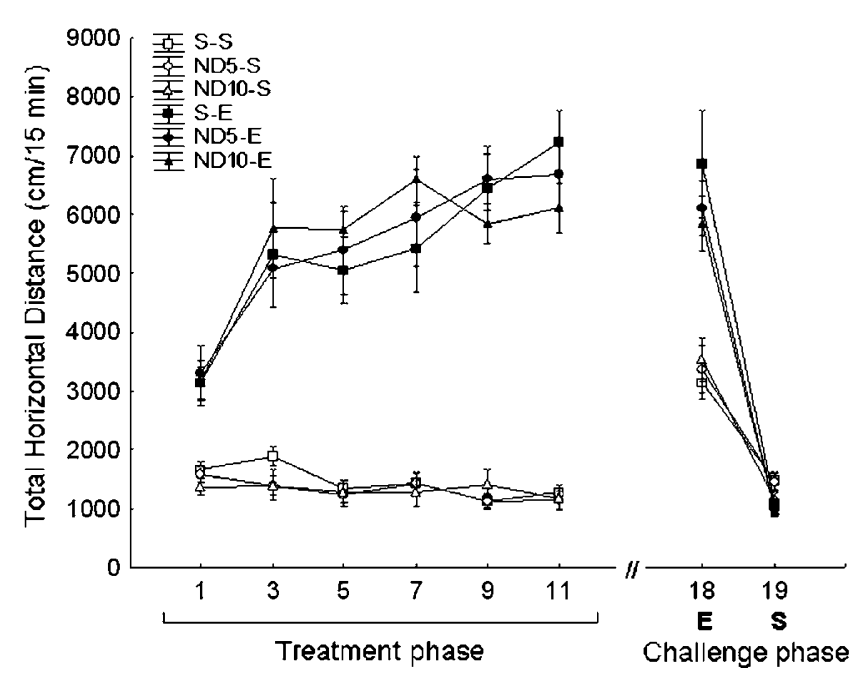

Figure 3 Effects of naltrindole on ethanol sensitization. Group means $( \pm$ SEM) for the last $15 \mathrm{~min}$ of a 20 -min test are presented. Numbers in the abscise axis refer to the day of the experiment. On days I-II mice received, every other day, the treatments indicated in the legend ( $S$, saline; $\mathrm{E}$, ethanol; ND5, naltrindole $5 \mathrm{mg} / \mathrm{kg}$; NDI0, naltrindole $10 \mathrm{mg} / \mathrm{kg}$ ). On days 18 and 19 all mice received ethanol and saline, respectively. Through all the experiment ethanol was injected at the dose of $2.5 \mathrm{~g} / \mathrm{kg}$. administered under two different treatment conditions, $20 \mathrm{~h}$ (Figure 4) or $15 \mathrm{~min}$ (Figure 5) before ethanol. When naloxonazine was given $20 \mathrm{~h}$ before ethanol, it did not alter the development of sensitization to ethanol. During the treatment phase, the ethanol $\left(\mathrm{F}_{1,50}=464.32 ; p<0.01\right)$ and trial factors $\left(\mathrm{F}_{5,250}=11.71 ; p<0.01\right)$ were found significant, but naloxonazine dose lacked effect and did not interact with any other factor. The ethanol challenge revealed a greater response to ethanol $\left(\mathrm{F}_{1,50}=45.32 ; p<0.01\right)$ in all

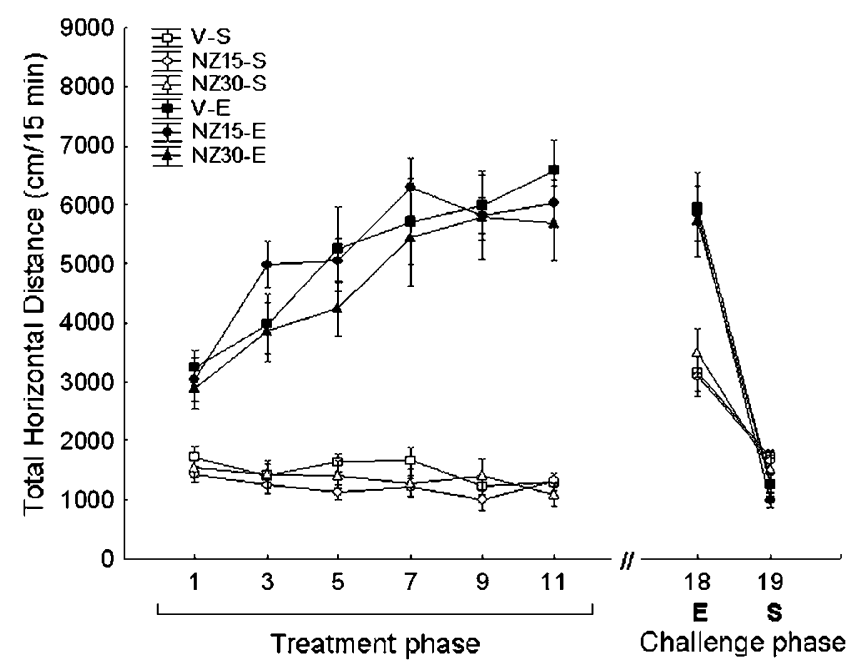

Figure 4 Effects of naloxonazine, given $20 \mathrm{~h}$ before, on ethanol sensitization. Group means ( \pm SEM) for the last 15 min of a 20 -min test are presented. Numbers in the abscise axis refer to the day of the experiment. On days I-I I mice received, every other day, the treatments indicated in the legend. ( $V$, vehicle; $E$, ethanol; NZI5, naloxonazine I $5 \mathrm{mg}$ / $\mathrm{kg}$; NZ30, naloxonazine $30 \mathrm{mg} / \mathrm{kg}$ ). On days 18 and 19 all mice received ethanol and saline, respectively. Through all the experiment ethanol was injected at the dose of $2.5 \mathrm{~g} / \mathrm{kg}$.

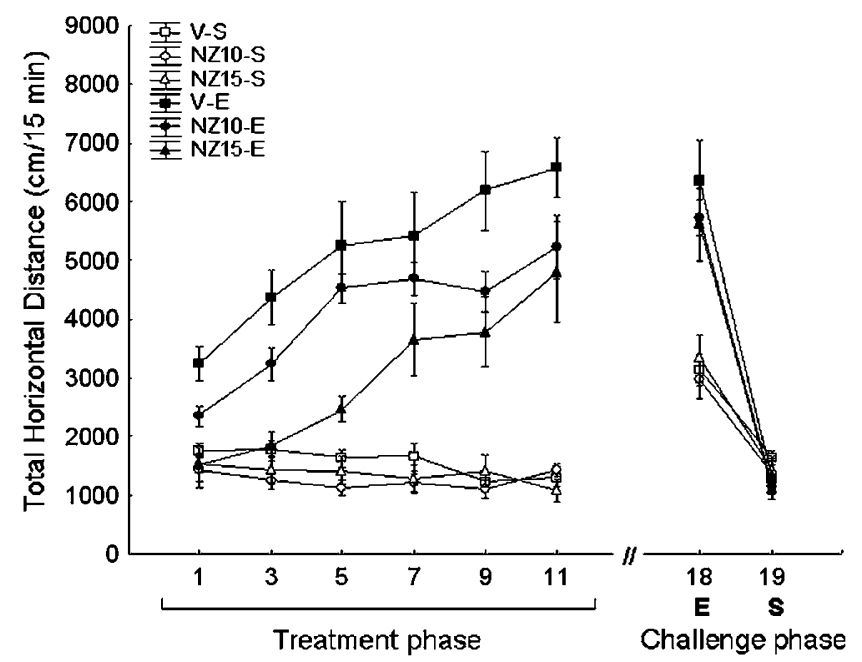

Figure 5 Effects of naloxonazine, given $15 \mathrm{~min}$ before, on ethanol sensitization. Group means ( \pm SEM) for the last 15 min of a 20 -min test are presented. Numbers in the abscise axis refer to the day of the experiment. On days I-I I mice received, every other day, the treatments indicated in the legend. ( $V$, vehicle; $\mathrm{E}$, ethanol; NZI0, naloxonazine $10 \mathrm{mg} / \mathrm{kg}$; NZI5, naloxonazine $15 \mathrm{mg} / \mathrm{kg}$ ). On days 18 and 19 all mice received ethanol and saline, respectively. Through all the experiment ethanol was injected at the dose of $2.5 \mathrm{~g} / \mathrm{kg}$. 


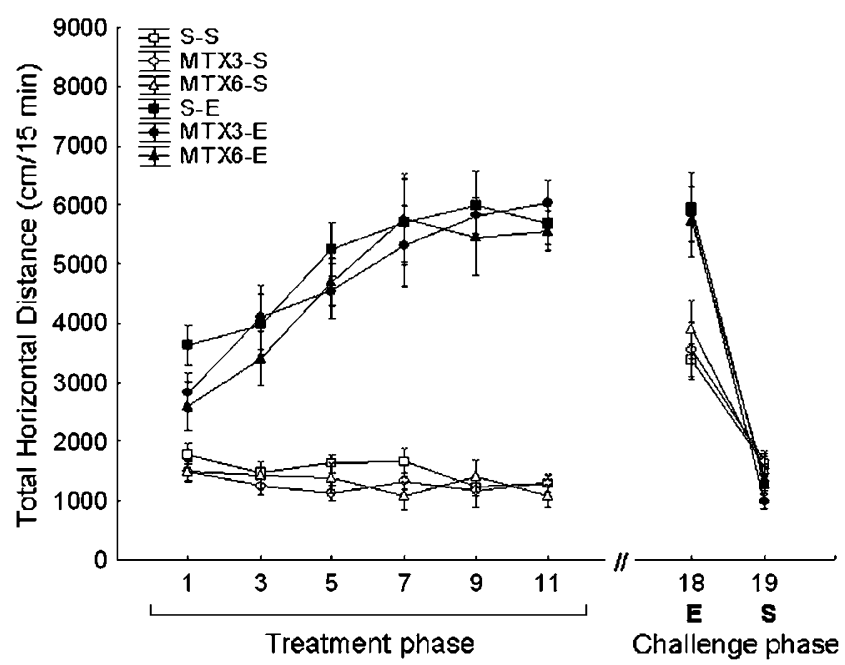

Figure 6 Effects of 3-methoxynaltrexone on ethanol sensitization. Group means $( \pm$ SEM) for the last 15 min of a 20 -min test are presented. Numbers in the abscise axis refer to the day of the experiment. On days II I mice received, every other day, the treatments indicated in the legend (S, saline; E, ethanol; MTX3, 3-methoxynaltrexone $3 \mathrm{mg} / \mathrm{kg}$; MTX6, 3methoxynaltrexone $6 \mathrm{mg} / \mathrm{kg}$ ). On days 18 and 19 all mice received ethanol and saline, respectively. Through all the experiment ethanol was injected at the dose of $2.5 \mathrm{~g} / \mathrm{kg}$.

groups that received ethanol during the treatment phase regardless of the pretreatment. No differences among groups were found on day 19 (saline challenge). When naloxonazine was given $15 \mathrm{~min}$ before ethanol, the development of sensitization was significantly altered. ANOVA analysis for the treatment phase revealed a main effect of naloxonazine dose $\left(\mathrm{F}_{2,49}=14.26 ; p<0.01\right)$ and a naloxonazine dose $\times$ ethanol dose interaction $\left(\mathrm{F}_{2,49}=9.68 ; p<0.01\right)$. Also, the effect of ethanol $\left(\mathrm{F}_{1,49}=225.58 ; p<0.01\right)$ and the ethanol $\times$ trial interaction $\left(\mathrm{F}_{5,245}=13.77 ; p<0.01\right)$ were found to be statistically significant; however, the naloxonazine dose $\times$ ethanol dose $\times$ trial interaction was not significant. The ethanol challenge, however, revealed that regardless of the pretreatment, all groups treated with ethanol during the treatment phase displayed a sensitized response to ethanol as only the treatment factor was found significant $\left(\mathrm{F}_{1,49}=42.80 ; p<0.01\right)$. There were no differences among groups on day 19 (ie the saline challenge day).

\section{Experiment 6}

Administration of 3-methoxyanaltrexone (Figure 6) did not alter the ability of ethanol to induce sensitization to its locomotor stimulating effects. As a lack of the antagonist dose $\times$ ethanol dose $\times$ trial interaction was not found, we did not analyze the effects of this compound on acute ethanol stimulation, although a modestly reduced response to ethanol was present on day 1. ANOVA for the treatment phase showed only a significant effect of ethanol dose $\left(\mathrm{F}_{1,50}=381.99 ; \quad p<0.01\right)$, trial factor $\left(\mathrm{F}_{5,250}=12.79\right.$; $p<0.01)$, and ethanol dose $\times$ trial interaction $\left(\mathrm{F}_{5,250}=\right.$ $19.19 ; p<0.01)$. This lack of effect of 3-methoxyanaltrexone was also found on day 18 (ie the ethanol challenge). In fact, a sensitized response to ethanol was found in all groups that previously received ethanol (ethanol treatment: $\left.\mathrm{F}_{1,50}=29.98 ; p<0.01\right)$ despite that some of them were administered with this $\mathrm{mu}_{3}$ antagonist. The saline challenge did not reveal any significant difference among groups.

\section{DISCUSSION}

The findings of the present study provide new insights into the involvement of the endogenous opioid system in the behavioral effects of ethanol. The current studies demonstrated that the neural processes underlying development of sensitization to the locomotor stimulating effects of ethanol require the activation of $\mathrm{mu}$, but not delta opioid receptors. The role of specific subtypes of the mu opioid receptor (ie $\mathrm{mu}_{1+2}$ or $\mathrm{mu}_{3}$ ) in ethanol sensitization, however, appears to be limited; as we found that the functional relevance of these subtypes is restricted to the acute locomotor effects of ethanol.

Data demonstrated robust sensitization to the locomotor activating effects of ethanol, as has previously been reported for Swiss mice (Camarini et al, 2000b; Miquel et al, 2003). Ethanol $(2.5 \mathrm{~g} / \mathrm{kg})$ produced a significant increase in locomotor activity when acutely administered. This effect increased progressively across the sessions and ended up reaching a plateau, indicating that our protocol led to the development of a ceiling effect on the locomotor stimulation produced by repeated ethanol administration. The sensitized response to ethanol was also evident when mice were tested following an abstinence period of 7 days, suggesting, as previously reported (Lessov and Phillips, 1998), persistent neural changes induced by ethanol. Interestingly, it has been postulated that such persistence could be associated with potentially permanent adaptations in neural pathways important for the motivational properties of drugs of abuse (Kalivas et al, 1993; Robinson and Berridge, 1993). We also observed that mice sensitized to ethanol did not show a conditioned locomotor response to the environment where testing with ethanol occurred. On the last day of the experiments, mice treated with repeated ethanol or saline did not differ in their locomotor response to a saline injection. The absence of any conditioned effect is critical to interpret the effect of pharmacological compounds that prevent drug-induced sensitization. If a conditioned effect were present, it would be difficult to discern whether the prevention of sensitization is due to a blockade of the mechanisms that underlie sensitization or whether this blockade is actually achieved by disrupting the associative memories that account for the conditioned locomotor effect (Cunningham and Noble, 1992).

Our results showed that naltrexone, at doses of 1 and $2 \mathrm{mg} / \mathrm{kg}$, prevented the development of ethanol sensitization; an effect that parallels previous data using naloxone (Camarini et al, 2000b). Across the treatment phase, mice that were injected with naltrexone displayed an attenuated locomotor response to ethanol, but an unaffected response to saline. Interestingly, when challenged with ethanol (in absence of naltrexone), those groups previously treated with naltrexone and ethanol displayed a magnitude of locomotor stimulation not different from that exhibited by mice that experienced the effects of ethanol for the first time. Both our results and those reported by Camarini et al (2000b) are 
obtained using doses of naltrexone and naloxone (close to $1 \mathrm{mg} / \mathrm{kg}$ ) that are supposed to act selectively at mu opioid receptors (Takemori and Portoghese, 1984; Williams et al, 2001), suggesting that these particular opioid receptors may be critically involved in ethanol sensitization. This hypothesis seems to be convincing as we found that the selective mu opioid receptor antagonist CTOP $(1.5 \mathrm{mg} / \mathrm{kg})$, prevented ethanol sensitization without affecting behavior of salinetreated mice. As there are no precedent data using specific $\mathrm{mu}$ opioid receptor antagonists on ethanol-induced locomotor behaviors, it is also noteworthy that CTOP dosedependently reduced the acute stimulatory effects of ethanol.

Our results indicated that delta opioid receptors are not involved in the development of behavioral sensitization to ethanol, as we found that naltrindole, an antagonist selective for delta opioid receptors (Portoghese et al, 1988) failed to prevent the development of ethanol sensitization. It seems unlikely that the lack of effect of naltrindole on ethanol sensitization could be explained by an insufficient dose, as we used doses similar or even higher than those reported to be effective in reducing, for instance, voluntary ethanol consumption or the conditioned reinstatement of ethanol-seeking behavior (Ciccocioppo et al, 2002; Hyytia and Kiianmaa, 2001; Kim et al, 2000). The current results suggest, therefore, that the neural adaptations responsible for the development of sensitization to ethanol require the activation of mu but not delta opioid receptors.

Although a single gene encoding the mu opioid receptor (MOR-1) has been cloned, several forms of the mu receptor mRNA arising from alternative mRNA slicing have been reported (Pan et al, 2001; Pasternak, 2001a, b). Based on a differential antagonism of the analgesic effects of several opiate drugs as well as on radioligand binding studies, compounds that can functionally differentiate three subtypes of $\mathrm{mu}$ opioid receptors $\left(\mathrm{mu}_{1}, \mathrm{mu}_{2}\right.$, and $\left.\mathrm{mu}_{3}\right)$ have been identified (Pasternak, 2001a,b; Cadet et al, 2003). Interestingly, these subtypes of mu receptor have been implicated in some of the behavioral effects of ethanol. For instance, the antagonism of $\mathrm{mu}_{1}$ opioid receptors has been found to reduce conditioned ethanol-seeking behavior (Ciccocioppo et al, 2002) but only modestly decreased voluntary ethanol intake (Honkanen et al, 1996; Franck et al, 1998). The blockade of both of $\mathrm{mu}_{1+2}$ receptors resulted in a reduction in ethanol consumption as well as a decrease in the discriminative effects of ethanol (Mhatre and Holloway, 2003). Recently, $\mathrm{mu}_{1+2}$ and $\mathrm{mu}_{3}$, but not $\mathrm{mu}_{1}$ opioid receptors, have been found to mediate the acute locomotor stimulating actions of ethanol (Pastor et al, 2005).

In the present study, however, we observed that neither the antagonism of $\mathrm{mu}_{1}$ (naloxonazine, $20 \mathrm{~h}$ before ethanol) nor $\mathrm{mu}_{3}$ opioid receptors (3-methoxynaltrexone) affected sensitization to ethanol, despite a modest decrease in acute ethanol-induced stimulation that was found with 3-methoxynaltrexone. The blockade of $\mathrm{mu}_{1+2}$ receptors (naloxonazine, $15 \mathrm{~min}$ before ethanol) attenuated the acute locomotor stimulating effects of ethanol and delayed, but did not prevent sensitization to ethanol. It has to be noted that currently there are no pharmacological tools to specifically block $\mathrm{mu}_{2}$ receptors. However, there is little evidence supporting a hypothesis that $\mathrm{mu}_{2}$ receptors may underlie ethanol sensitization, as antagonism of $\mathrm{mu}_{1+2}$ opioid receptors lacked effect at blocking sensitization. Other possibilities, such as the concurrent blockade of $\mathrm{mu}_{1+3}$ or $\mathrm{mu}_{2+3}$ opioid receptors, can be hypothesized as putative mechanisms underlying sensitization to ethanol. However, the antagonism of $\mathrm{mu}_{1}$ or $\mathrm{mu}_{3}$ receptors, when tested independently, had no effect on ethanol sensitization; it seems very unlikely, thus, that the concurrent inactivation of $\mathrm{mu}_{1+3}$ opioid receptors could result in a blockade of sensitization. Also, limited evidence supports an involvement of $\mathrm{mu}_{2+3}$ opioid receptors, as we found that the blockade of $\mathrm{mu}_{3}$ or $\mathrm{mu}_{1+2}$ opioid receptors lacked effect at preventing sensitization to ethanol. Altogether, we tentatively propose that a concurrent blockade of all mu opioid receptor subtypes may be required to block the development of behavioral sensitization to ethanol.

As proposed elsewhere (Meyer and Phillips, 2003), the interpretation of the effects of compounds that prevent ethanol sensitization is challenged by the fact that these drugs also block the acute stimulant effects of ethanol. It might be that in order for sensitization to develop animals require the experience of the acute stimulatory effects of ethanol (Meyer and Phillips, 2003). In the present study, however, we observed that animals treated with $1 \mathrm{mg} / \mathrm{kg}$ of CTOP did not show acute stimulation or development of sensitization during the treatment phase. Nevertheless, when challenged with ethanol (in absence of CTOP) 7 days after the end of the treatment phase, they displayed a sensitized response to ethanol. Thus, while the debate on whether or not development of sensitization to ethanol requires exposure to its stimulant effects remains interesting, we consider that the prevention of sensitization that we obtained with naltrexone and CTOP may be achieved by blocking the neural mechanism underlying sensitization. This conclusion is additionally supported by the fact that changes in the pharmacokinetics of ethanol cannot be explaining the effect of these compounds on ethanol sensitization, as we found that blood ethanol concentrations were not modified by naltrexone or CTOP.

The hypothesis that ethanol can interfere the coupling of mu opioid receptors to $G$ proteins has been suggested as an explanation for the involvement of $\mathrm{mu}$ receptors in the behavioral effects of ethanol (Chen and Lawrence, 2000; Saland et al, 2004). To our understanding, however, the most convincing proposal to comprehend the neural mechanism by which these receptors participate in ethanol sensitization may be related to the actions of the mu opioid receptor endogenous ligand, $\beta$-endorphin. Ethanol administration produces an increase in $\beta$-endorphin release, as measured by in vivo microdialysis in the NAcb (Olive et al, 2001; Marinelli et al, 2003). Also, acute administration of ethanol increased $\beta$-endorphin neurotransmission in the ventral tegmental area (VTA) (Rasmussen et al, 1998). The brain sites of synthesis of the $\beta$-endorphin precursor, proopiomelanocortin (POMc) primarily include the hypothalamic arcuate nucleus (ArcN) (Khatchaturian et al, 1985). Interestingly, lesions of the $\mathrm{ArcN}$ prevented the development of behavioral sensitization to ethanol (Miquel et al, 2003). The parallelism between the effects of an ArcN lesion and the antagonism of mu opioid receptors on ethanol strongly suggests that the involvement of the opioid 
system in ethanol sensitization could depend on the activation of $\mathrm{mu}$ opioid receptors by ethanol-induced release of $\beta$-endorphin.

It is well established that the VTA and the NAcb, as well as the prefrontal cortex, are critical contributors to druginduced behavioral sensitization (Pierce and Kalivas, 1997; Robinson and Kolb, 1997; Vanderschuren and Kalivas, 2000). The POMc projections arising from the ventrolateral part of the ArcN project to the VTA and the NAcb (Chronwall, 1985), and have been suggested to control basal DA release in the NAcb (Spanagel et al, 1992). The release of DA in the NAcb seems to be evoked indirectly by the activation of mu opioid receptors located on VTA GABAergic interneurons (Leone et al, 1991; Longoni et al, 1991; Spanagel et al, 1992). This neurochemical pathway has also been proposed to explain ethanol-induced increases in DA release in the NAcb, as opioid receptor antagonists prevented ethanol-induced activation of VTA DA neurons (Gonzales and Weiss, 1998; Tanda and Di Chiara, 1998). Altogether, these data support the hypothesis that mesolimbic DA pathways could be of critical importance to explain ethanol-induced sensitization. However, it is currently difficult to reach clear conclusions on the involvement of DA in sensitization to ethanol. It has been demonstrated that chronic administration of ethanol sensitized DA neurons in the VTA (Brodie, 2002) and provoked long-term changes in the DAergic terminals of the $\mathrm{NAcb}$ and the dorsal striatum (Nestby et al, 1997). Also, increases in $\mathrm{DA} \mathrm{D}_{2}$ receptor binding have been described in mice sensitized to ethanol (Souza-Formigoni et al, 1999). However, mice lacking DA $\mathrm{D}_{2}$ receptors did not show attenuated ethanol-induced sensitization (Palmer et al, 2003) and the nonspecific DA receptor antagonist haloperidol failed at preventing sensitization to ethanol (Broadbent et al, 1995).

Although the role of DA in ethanol sensitization requires further research, it might be possible that opioid receptors others than those located in brain structures that modulate DA activity could be involved in ethanol sensitization. For instance, it has been demonstrated that mu opioid receptors in the ventral pallidum (VP) support morphine-induced behavioral sensitization, as injections of the mu receptor antagonist CTOP into the VP blocked behavioral sensitization to morphine (Johnson and Napier, 2000). We hypothesize that this may be also explaining why naltrexone and CTOP blocked ethanol sensitization. Data indicate that the VP is involved in both the motor (Austin and Kalivas, 1990; Hoffman et al, 1991) and the incentive (Hiroi and White, 1993; McFarland and Kalivas, 2001) properties of psychomotor stimulants and opiates. At this respect, it is not presently known whether the ArcN sends endorphinic projections to the VP. It is clear, though, that the VP serves as a primary output for the NAcb (Chrobak and Napier, 1993; Groenewegen and Russchen, 1984). Because an ArcNNAcb projection has been described (Chronwall, 1985), it could be possible that the changes in the VP that may be necessary for the development of ethanol sensitization could be prevented by blocking the action of $\beta$-endorphins at the level of the NAcb and/or by blocking mu receptors in the VP.

In summary, these findings extend our understanding of the neurochemistry that underlie ethanol-induced beha- vioral sensitization, a characteristic sequelae of repeated ethanol exposure with critical implications for addiction. Future experiments will be devoted to explore all these above proposed hypotheses. First, direct evidence on the role of $\beta$-endorphins on ethanol sensitization is required. Second, a precise neuroanatomic analysis of the importance of mu opioid repectors in the mesopallidal system in ethanol sensitization would be enlightening.

\section{ACKNOWLEDGEMENTS}

This work was supported by grants from CICYT (BSO200200631) and from Red de Trastornos Adictivos, Ministerio de Sanidad y Consumo (05I044.01/1) Spain. We acknowledge gratefully the technical assistance provided by Alicia Dosda and Gemma Caballer and the helpful insights provided by Dr Carles Sanchis-Segura and Sarah E Holstein. R Pastor was supported by a fellowship from the Agencia Valenciana de Ciencia y Tecnología (CTBPRB/2002/187), Generalitat Valenciana, Spain.

\section{REFERENCES}

Austin MC, Kalivas PW (1990). Enkephalinergic and GABAergic modulation of motor activity in the ventral pallidum. $J$ Pharmacol Exp Ther 252: 1370-1377.

Badiani A, Oates MM, Robinson TE (2000). Modulation of morphine sensitization in the rat by contextual stimuli. Psychopharmacology 151: 273-282.

Boehm II SL, Schafer GL, Phillips TJ, Browman KE, Crabbe JC (2000). Sensitivity to ethanol-induced motor incoordination in 5-HT(1B) receptor null mutant mice is task-dependent: implications for behavioral assessment of genetically altered mice. Behav Neurosci 114: 401-409.

Broadbent J, Grahame NJ, Cunningham CL (1995). Haloperidol prevents ethanol-stimulated locomotor activity but fails to block sensitization. Psychopharmacology 120: 475-482.

Broadbent J, Kampmueller KM, Koonse SA (2003). Expression of behavioral sensitization to ethanol by DBA/2J mice: the role of NMDA and non-NMDA glutamate receptors. Psychopharmaco$\log y$ 167: 225-234.

Brodie MS (2002). Increased ethanol excitation of dopaminergic neurons of the ventral tegmental area after chronic ethanol treatment. Alcohol Clin Exp Res 26: 1024-1030.

Cadet P, Mantiene KJ, Stefano GB (2003). Molecular identification and functional expression of mu 3, a novel alternatively spliced variant of the human mu opiate receptor gene. J Immunol 170: 5118-5123.

Camarini R, Frussa-Filho R, Monteiro MG, Calil HM (2000a). MK801 blocks the development of behavioral sensitization to the ethanol. Alcohol Clin Exp Res 24: 285-290.

Camarini R, Nogueira Pires ML, Calil HM (2000b). Involvement of the opioid system in the development and expression of sensitization to the locomotor-activating effect of ethanol. Int $J$ Neuropsychopharmacol 3: 303-309.

Chen F, Lawrence AJ (2000). Effect of chronic ethanol and withdrawal on the mu-opioid receptor- and 5-Hydroxytryptamine $(1 \mathrm{~A})$ receptor-stimulated binding of [(35)S] Guanosine- $5^{\prime}$ $O$-(3-thio)triphosphate in the fawn-hooded rat brain: a quantitative autoradiography study. J Pharmacol Exp Ther 293: 159-165.

Chrobak JJ, Napier TC (1993). Opioid and GABA modulation of accumbens-evoked ventral pallidal activity. J Neural Trans 93: $123-143$. 
Chronwall BM (1985). Anatomy and physiology of the neuroendocrine arcuate nucleus. Peptides 6: 1-11.

Ciccocioppo R, Martin-Fardon R, Weiss F (2002). Effect of selective blockade of $\mathrm{mu}(1)$ or delta opioid receptors on reinstatement of alcohol-seeking behavior by drug-associated stimuli in rats. Neuropsychopharmacology 27: 391-399.

Cunningham CL, Noble DeC (1992). Conditioned activation induced by ethanol: role in sensitization and conditioned place preference. Pharmacol Biochem Behav 43: 307-313.

Dudek BC, Tritto T (1994). Biometrical genetic analysis assay of the psychomotor stimulant effect of ethanol. Alcohol Clin Exp Res 16: 347-353.

Franck J, Lindholm S, Raaschou P (1998). Modulation of volitional ethanol intake in the rat by central delta-opioid receptors. Alcohol Clin Exp Res 22: 1185-1189.

Gonzales RA, Weiss F (1998). Suppression of ethanol-reinforced behavior by naltrexone is associated with attenuation of the ethanol-induced increase in dialysate dopamine levels in the nucleus accumbens. J Neurosci 18: 10663-10671.

Groenewegen HJ, Russchen FT (1984). Organization of the efferent projections of the nucleus accumbens to pallidal, hypothalamic, and mesencephalic structures: a tracing and immunohistochemical study in the cat. J Comp Neurol 223: 347-367.

Hall FS, Sora I, Uhl GR (2001). Ethanol consumption and reward are decreased in mu-opiate receptor knockout mice. Psychopharmacology 154: 43-49.

Hiroi N, White NM (1993). The ventral pallidum area is involved in the acquisition but not expression of the amphetamine conditioned place preference. Neurosci Lett 156: 9-12.

Hoffman DC, West TEG, Wise RA (1991). Ventral pallidal microinjections of receptor-selective opioid agonists produce differential effects on circling and locomotor activity in rats. Brain Res 550: 205-212.

Honkanen A, Vilamo L, Wegelius K, Sarviharju M, Hyytia P, Corp ER (1996). Alcohol drinking is reduced by a mul but not by a delta opioid receptor antagonist in alcohol-preferring rats. Eur J Pharmacol 23: 7-13.

Hyytia P, Kiianmaa K (2001). Suppression of ethanol responding by centrally administered CTOP and naltrindole in AA and Wistar rats. Alcohol Clin Exp Res 25: 25-33.

Johnson PI, Napier TC (2000). Ventral pallidal injections of a mu antagonist block the development of behavioral sensitization to systemic morphine. Synapse 38: 61-70.

Kalivas PW, Sorg BA, Hooks MS (1993). The pharmacology and neural circuitry of sensitization to psychostimulants. Behav Pharmacol 4: 315-334.

Kalivas PW, Striplin CD, Steketee JD, Klitenick MA, Duffy P (1992). Cellular mechanisms of behavioral sensitization to drugs of abuse. Ann NY Acad Sci 654: 128-135.

Kelley AE (1993). Locomotor activity and exploration. In Sahgal A (ed). Behavioural Neuroscience: A Practical Approach. Oxford University Press: Oxford. pp 1-21.

Khatchaturian H, Lewis ME, Schäfer MKH, Watson SJ (1985). Anatomy of CNS opioid systems. Trends Neurosci 8: 111-119.

Kim SG, Stromberg MF, Kim MJ, Volpicelli JR, Park JM (2000). The effect of antagonists selective for mu- and delta-opioid receptor subtypes on alcohol consumption in C57BL/6 mice. Alcohol 22: 85-90.

Leone P, Pocock D, Wise RA (1991). Morphine-dopamine interaction: ventral tegmental morphine increases nucleus accumbens dopamine release. Pharmacol Biochem Behav 39: 469-472.

Lessov CN, Phillips TJ (1998). Duration of sensitization to the locomotor stimulant effects of ethanol in mice. Psychopharmacology 135: 374-382.

Lett BT (1989). Repeated exposures intensify rather than diminish the rewarding effects of amphetamine, morphine, and cocaine. Psychopharmacology 98: 357-362.
Ling GS, Simantov R, Clark JA, Pasternak GW (1986). Naloxonazine actions in vivo. Eur J Pharmacol 129: 33-38.

Longoni R, Spina L, Mulas A, Carboni E, Garau L, Melchiorri P et al (1991). (D-Ala2) deltorphin II: D1-dependent stereotypies and stimulation of dopamine release in the nucleus accumbens. J Neurosci 11: 1565-1576.

Marinelli PW, Quirion R, Gianoulakis C (2003). A microdialysis profile of beta-endorphin and catecholamines in the rat nucleus accumbens following alcohol administration. Psychopharmaco$\log y$ 169: 60-67.

McFarland K, Kalivas PW (2001). The circuitry mediating cocaineinduced reinstatement of drug-seeking behavior. J Neurosci 21: 8655-8663.

Meyer PJ, Palmer AA, McKinnon CS, Phillips TJ (2005). Behavioral sensitization to ethanol is modulated by environmental conditions, but is not associated with cross-sensitization to allopregnanolone or pentobarbital in DBA/2J mice. Neuroscience 131: 263-273.

Meyer PJ, Phillips TJ (2003). Bivalent effects of MK-801 on ethanolinduced sensitization do not parallel its effects on ethanolinduced tolerance. Behav Neurosci 117: 641-649.

Mhatre M, Holloway F (2003). $\mu 1$-opioid antagonist naloxonazine alters ethanol discrimination and consumption. Alcohol 29: 109-116.

Miquel M, Font L, Sanchis-Segura C, Aragon CMG (2003). Neonatal administration of monosodium glutamate prevents the development of ethanol- but not psychostimulant-induced sensitization: a putative role of the arcuate nucleus. Eur $J$ Neurosci 17: 2163-2170.

Nestby P, Vanderschuren LJ, De Vries TJ, Hogenboom F, Wardeh G, Mulder AH et al (1997). Ethanol, like psychostimulants and morphine, causes long-lasting hyperreactivity of dopamine and acetylcholine neurons of rat nucleus accumbens: possible role in behavioural sensitization. Psychopharmacology 133: $69-76$.

Olive MF, Koenig HN, Nannini MA, Hodge CW (2001). Stimulation of endorphin neurotransmission in the nucleus accumbens by ethanol, cocaine, and amphetamine. J Neurosci 21: RC184.

Palmer AA, Low MJ, Grandy DK, Phillips TJ (2003). Effects of a Drd2 deletion mutation on ethanol-induced locomotor stimulation and sensitization suggest a role for epistasis. Behav Genet 33: 311-324.

Pan YX, Xu J, Mahurter L, Bolan E, Xu M, Pasternak GW (2001). Generation of the mu-opioid receptor (MOR-1) protein by three new splice variants of the Oprm gene. Proc Natl Acad Sci USA 98: 14084-14089.

Pasternak GW (2001a). Insights into mu-opioid pharmacology the role of mu-opioid receptor subtypes. Life Sci 68: 2213-2219.

Pasternak GW (2001b). Incomplete cross tolerance and multiple mu opioid peptide receptors. Trends Pharmacol Sci 22: 67-70.

Pastor R, Sanchis-Segura C, Aragon CMG (2002). Ethanolstimulated behaviour in mice is modulated by brain catalase activity and $\mathrm{H} 2 \mathrm{O} 2$ rate of production. Psychopharmacology 165 : 51-59.

Pastor R, Sanchis-Segura C, Aragon CMG (2005). Effect of selective antagonism of $\mathrm{mu}(1)-, \mathrm{mu}(1 / 2)-, \mathrm{mu}(3)-$, and delta-opioid receptors on the locomotor-stimulating actions of ethanol. Drug Alcohol Depend 78: 289-295.

Phillips TJ, Dickinson S, Burkhart-Kasch S (1994). Behavioral sensitization to drug stimulant effects in C57BL/6J and DBA/2J inbred mice. Behav Neurosci 108: 789-803.

Piazza PV, Deminière JM, Le Moal M, Simon H (1989). Factors that predict individual vulnerability to amphetamine self-administration. Science 245: 1511-1513.

Pierce RC, Kalivas PW (1997). A circuitry model of the expression of behavioral sensitization to amphetamine-like psychostimulants. Brain Res Rev 25: 192-216. 
Portoghese PS, Sultana M, Takemori AE (1988). Naltrindole, a highly selective and potent non-peptide delta opioid receptor antagonist. Eur J Pharmacol 146: 185-186.

Quertemont E, Green HL, Grant KA (2003). Brain ethanol concentrations and ethanol discrimination in rats: effects of dose and time. Psychopharmacology 168: 262-270.

Rasmussen DD, Bryant CA, Boldt BM, Colasurdo EA, Levin N, Wilkinson CW (1998). Acute alcohol effects on opiomelanocortinergic regulation. Alcohol Clin Exp Res 22: 789-801.

Robinson TE, Berridge KC (1993). The neural basis of drug craving: an incentive sensitization theory of addiction. Brain Res Rev 18: 247-291.

Robinson TE, Kolb B (1997). Persistent structural modifications in nucleus accumbens and prefrontal cortex neurons produced by previous experience with amphetamine. J Neurosci 17: 84918497.

Saland LC, Abeyta A, Frausto S, Raymond-Stintz M, Hastings CM, Carta $M$ et al (2004). Chronic ethanol consumption reduces delta-and mu-opioid receptor-stimulated G-protein coupling in rat brain. Alcohol Clin Exp Res 281: 98-104.

Sanchis-Segura C, Pastor R, Aragon CMG (2004). Opposite effects of acute versus chronic naltrexone administration on ethanolinduced locomotion. Behav Brain Res 153: 61-67.

Souza-Formigoni ML, De Lucca EM, Hipolide DC, Enns SC, Oliveira MG, Nobrega JN (1999). Sensitization to ethanol's stimulant effect is associated with region-specific increases in brain D2 receptor binding. Psychopharmacology 146: 262-267.

Spanagel R, Herz A, Shippenberg TS (1992). Opposing tonically active endogenous opioid systems modulate the mesolimbic dopaminergic pathway. Proc Natl Acad Sci USA 89: 2046-2050.

Stewart J, Badiani A (1993). Tolerance and sensitization to the behavioral effects of drugs. Behav Pharmacol 4: 289-312.

Takemori AE, Portoghese PS (1984). Comparative antagonism by naltrexone and naloxone of mu, kappa, and delta agonists. Eur J Pharmacol 104: 101-104.

Tanda G, Di Chiara G (1998). A dopamine-mul opioid link in the rat ventral tegmentum shared by palatable food (Fonzies) and non-psychostimulant drugs of abuse. Eur J Neurosci 10: $1179-1187$.

Vanderschuren LJ, Kalivas PW (2000). Alterations in dopaminergic and glutamatergic transmission in the induction and expression of behavioral sensitization: a critical review of preclinical studies. Psychopharmacology 51: 99-120.

Vezina P, Kim JH (1999). Metabotropic glutamate receptors and the generation of locomotor activity: interactions with midbrain dopamine. Neurosci Biobehav Rev 23: 577-589.

Williams JT, Christie MJ, Manzoni O (2001). Cellular and synaptic adaptations mediating opioid dependence. Physiol Rev 81: 299-343. 